the many unsolved problems that confront the experimentalist and the clinician. A logical approach would seem to be to use as the therapeutic regimen a combination of two or more drugs each having a high antagonistic efficacy for tubercle bacilli. Streptomycin utilized simultaneously with some other (as yet unknown) antibiotic might prove effective. Streptomycin combined with sulphone compounds or with other synthetic anti-tuberculosis drugs offers possibilities that are now being explored.

\section{Final Comment}

During recent years studies in the antibacterial attack on tuberculosis have yielded results sufficient to change to a considerable degree many of the previously held therapeutic concepts of tuberculosis. Most important, it has been adequately demonstrated that this disease is no longer beyond the range of specific drug therapy. Instead, the vulnerability of tuberculous infections to a chemotherapeutic attack has been established experimentally and clinically. While to date the completely ideal anti-tuberculosis drug has not been reported it seems probable that substances equal or superior in effectiveness to known agents may be found. These possibilities warrant expenditure of great effort, and this search may become one of the most important and exciting adventures in medical research.

In the meantime streptomycin seems likely to become generally accepted as a useful drug in certain types of dinical tuberculosis. It must, however, be used intelligently, with full recognition of its shortcomings and limitations. It should frequently be used in combination with other effective methods of treatment, rather than as a substitute for such proved therapeutic procedures as care in a sanatorium, collapse therapy, and surgery.

\section{REFERENCES}

Baggenstoss, A. H., Feldman, W. H., and Hinshaw, H. C. (1947). Amer. Rev. Tuberc., 55, 54.

Brown, H. A., and Hinshaw, H. C. (1946). Proc. Mayo Clin., 21, 347.

Cantani, A. (1885). Quoted by W. H. Florey, British Medical Journal, 1945, 2, 635

Council on Pharmacy and Chemistry (1947). J. Amer. med. Ass., 135, 634 .

Demerec, M. Quoted by F. R. Selbie (1946). Brit. med. Bull., 4, 267.

Faget, G. H., Pogge, R. C., Johansen, F. H., Fite, G. L., Prejean, B. M., and Gemar, Frank (1946). Int. J. Leprosy, 14, 30.

Feldman, W. H. (1946a). J. roy. Inst. publ. Hlth., 9, 267.

(1946b). Ibid., 9, 297.

(1946c). Ibid., 9, 343 .

and Hinshaw, H. C. (1944). Proc. Mayo Clin., 19, 593.

435 .

- and Mann, F. C. (1945). Ibid.. 52, 269.

and Mann, F. C. (1945). Ibid.. 52, 269.

Karlson, A. G., and Hinshaw, H. C. (1947). Amer. Rev. Tuberc., 56, 346 .

Figi, F. A., and Hinshaw, H. C. (1946). Trans. Amer. Acad. Ophthal. Otolaryng., 50, 93.

Fowler, E. P., and Seligman, Ewing (1947). J. Amer. med. Ass., $133,87$.

Glover, R. P., Clagett, O. T., and Hinshaw, H. C. (1947). Amer. Rev. Tuberc., 55, 418.

Hart. P. D'A. (1946). British Medical Journal, 2, 805, 849.

Hinshaw, H. C. (1947a). J. Lancet, 67, 131.

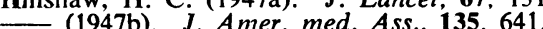

- and Feldman, W. H. (1944). Amer. Rev. Tuberc., 50, 202. and Feldman, W. H. (1944). Amer. Rev.

Karlson, A. G.. Feldman, W. H., and Hinshaw, H. C. (1947). Proc. Soc. exp. Biol., N.Y., 64, 6.

McDermott, Walsh (1947). Amer. J. Med.. 2, 491.

Moiitor, Hans (1947). Bull. N. Y. Acad. Med., 23, 196

Moiitor, Hans (1947). Bull. N. Y. Acad. Med., 23, 196. and Silber, R. H. (1946). J. Pharmacol., 86, 151.

OLeary, P. A., Ceder, E. T., Hinshaw, H. C., and Feldman, W. H. (1947). Arch. Derm. Syph., Chicago, 55, 222

Pyte, Mariorie M. (1947). Proc. Mayo Clin.. 22, 465.

Rist, N., Bloch, F., and Hamon, V. (1940). Ann. Inst. Pasteur, 64. 203.

Smith, Dorothy G., and Waksman, S. A. (1947). J. Bact., 54, 253.

Waksman, S. A. (1947). J. Amer. med. Ass., 135, 478.

Youmans, G. P., and McCarter, J. C. (1945). Amer. Rev. Tuberc. 52. 432 .

and Williston, Elizabeth H (1946). Proc. Soc. exp. Biol. N.Y. 63. 131

\section{CANCER OF THE STOMACH IN ADDISON'S ANAEMIA}

BY

\author{
W. A. BOURNE, M.D., F.R.C.P.
}

(From the Royal Sussex County and Hove General Hospitals)

Among some clinicians there is a feeling that patients suffering from pernicious anaemia are more liable to gastric carcinoma than normal individuals of the same age groups. Kaplan and Rigler (1945) suggested that this feeling had statistical backing, and reported (Kaplan and Rigler, 1947) 18 cases of cancer and 17 simple tumours in 259 cases of pernicious anaemia. During the past two years 15 of my own cases have been observed by radiograph and gastroscopy in the hope of detecting carcinoma of the stomach at an early stage. Occasional estimations of the blood sedimentation rate have also been made, since Whitby and Britton (1946) state that the test is of great value in suggesting the onset of carcinoma. Cases were not selected, and there can be no pretence that they form a series. These observations have resulted in the discovery of three cases of carcinoma in patients free from symptoms and clinical signs: one was certainly operable and one probably operable when first detected. One further case has been found to have a leiomyoma. Two others are under particular observation because of a persistently high blood sedimentation rate; one of these has a nodule of uncertain nature in the pyloric antrum.

The cases observed are here tabulated. The total is made up of 11 females and 4 males. Radiological examination consisted of a barium swallow, fluoroscopy, and, usually, a film. Gastroscopy was performed with the Hermon Taylor

\begin{tabular}{|c|c|c|c|c|c|c|c|}
\hline $\begin{array}{l}\text { Case } \\
\text { No. }\end{array}$ & Sex & Age & $\begin{array}{c}\text { Duration } \\
\text { of } \\
\text { Anaemia }\end{array}$ & $\begin{array}{c}X \text {-ray } \\
\text { Film }\end{array}$ & Gastroscopy & E.S.R. & Conclusion \\
\hline $\begin{array}{l}1 \\
2 \\
3 \\
4 \\
5 \\
6 \\
7 \\
8 \\
9\end{array}$ & $\begin{array}{l}\mathbf{F} \\
\mathrm{F} \\
\mathrm{F} \\
\mathrm{F} \\
\mathrm{F} \\
\mathbf{M} \\
\mathbf{F} \\
\mathbf{F} \\
\mathbf{M}\end{array}$ & $\begin{array}{l}41 \\
41 \\
47 \\
49 \\
50 \\
52 \\
55 \\
60 \\
65\end{array}$ & $\begin{array}{r}3 \\
7 \\
2 \\
4 \\
11 \\
1 \\
11 \\
4 \\
10\end{array}$ & $\begin{array}{c}\text { Normal } \\
\text { " } \\
\# \\
\# \\
\text { Ab"̈ormal }\end{array}$ & $\begin{array}{c}\bar{Z} \\
\overline{\text { Normal }} \\
\bar{Z} \\
\overline{\text { Polyp }} \\
\text { Abnormal }\end{array}$ & $\begin{array}{l}\overline{20} \\
1 \\
40 \\
\overline{7} \\
26 \\
=\end{array}$ & $\begin{array}{c}= \\
\bar{z} \\
\overline{=} \\
\text { Leiomyoma } \\
\text { Carcinoma }\end{array}$ \\
\hline $\begin{array}{l}10 \\
11\end{array}$ & $\mathbf{F}$ & $\begin{array}{l}70 \\
70\end{array}$ & $\begin{array}{l}13 \\
13\end{array}$ & $\begin{array}{l}\text { antrum } \\
\text { Normal } \\
\text { Abnormal }\end{array}$ & $\begin{array}{c}\text { antrum } \\
\text { Carcinoma }\end{array}$ & $\overline{-}$ & Carcinoma \\
\hline $\begin{array}{l}12 \\
13 \\
14\end{array}$ & $\begin{array}{l}\mathrm{F} \\
\mathrm{F} \\
\mathrm{F}\end{array}$ & $\begin{array}{l}73 \\
75 \\
75\end{array}$ & $\begin{array}{r}6 \\
2 \\
12\end{array}$ & Normal & 三 & $=$ & $\frac{\bar{Z}}{\text { Carcinoma }}$ \\
\hline 15 & $\mathbf{M}$ & 77 & 1 & Norm & $\begin{array}{c}\text { Nodule in } \\
\text { antrum }\end{array}$ & 30 & Solitary polyp \\
\hline
\end{tabular}

or Schindler instrument if the radiological report was doubtful, if there was failure to improve clinically, and once when there was a persistently high sedimentation rate in the absence of abnormal radiological findings. The sedimentation rate was determined by Wintrobe's method corrected for anaemia, and was asked for quite at random. It must be emphasized that no patient had dyspepsia when examined.

\section{Case 9}

A retired jockey aged 65 was diagnosed as suffering from pernicious anaemia in Berlin in 1937, and had been on liver treatment with satisfactory results thereafter. Though asymptomatic he was $x$-rayed on Sept. 18, 1945, and the report stated : "There is some rigidity in the prepyloric region which is somewhat suggestive of early scirrhous carcinoma, but it may be due only to fibrosis. If other signs are equivocal, a repeat examination in a few weeks' time would be advisable for comparison." Gastroscopy on Oct. 31 showed that the lower third of the stomach was fixed and pale, with no peristalsis. Laparotomy was performed on Feb. 27, 1946. At this time he 
was feeling fit, was putting on weight, had a good appetite with no abnormal symptoms, and nothing abnormal was found on clinical examination. A blood count showed : $\mathrm{Hb}, 98 \%$; red cells, 5,050,000 ; colour index, 0.97 ; white cells, 6,500 (polymorphs $84 \%$, lymphocytes $14 \%$, monocytes $1 \%$, eosinophils $1 \%)$; red cells normal.

At operation there was no evidence of neoplasm, though the stomach was not opened. He continued on liver therapy as before until, in March, 1947, he gave a four-weeks history of constant abdominal pain, worse after meals, and relieved by immediate vomiting of undigested food. During this four weeks his appetite had failed, he had lost $10 \mathrm{lb}$. $(4.5 \mathrm{~kg}$.) in weight, and the bowels were opened regularly. There was no paraesthesia. Clinically he was wasted, with a smooth tongue and flat nails. There was no abdominal tumour or lymph-node enlargement. The blood count showed : $\mathrm{Hb}, 64 \%$; red cells, $3,400,000$; white cells, 9,700 ; colour index, 0.94 ; the red cells showed a little anisocytosis and no evident macrocytosis. A test of occult blood in stools was positive. An alcohol test meal showed no free $\mathrm{HCl}$, no blood or bile, and no lactic acid. $X$-ray report stated : "There are huge irregular filling defects in the pyloric portion of the stomach, indicating the presence of a large tumour mass encroaching on the lumen of the stomach." Laparotomy on April 9 revealed a large carcinoma of the pyloric end of the stomach; glands in pyloric region, portal region, and fissure much enlarged. Post-colic jejunostomy was performed. The patient died on April 22.

Comment.-It seems very probable that when first operated on this patient, with radiological and gastroscopic abnormality in the lower third of the stomach, had early carcinomatous change, not detectable surgically. This did not show itself clinically for eighteen months, when, after only a month's symptoms, the diagnosis was certain. Achlorhydria and length of history render the diagnosis of pernicious anaemia probable. Surgical evidence confirms the radiological and gastroscopic impression that the original lesion was in the pyloric region.

\section{Case 14}

A housewife aged 75 had been treated for pernicious anaemia for twelve years with monthly liver injections. In May, 1947, she was admitted to hospital with a three-months history of vomiting three or four times daily at no special time, but occasionally after meals. Nausea and retching were frequent, with production of green bile. There was a non-localized gnawing feeling in the abdomen, but no true abdominal pain. One recent diarrhoeic attack occurred lasting 24 hours. She gave a long-standing history of piles with occasional bleeding, and of a productive cough with dyspnoea. She had recently lost some weight and had tended to constipation. There was no family history of anaemia. Clinically, the tongue was smooth, cracked, and shiny, the conjunctivae pale. Nothing significant was found except transient hypertension and crepitations at both lung bases. The abdomen appeared normal and there were no enlarged lymph nodes. Urinary culture was sterile, and the stools were negative for occult blood. A blood count on May 3 showed : red cells, 2.710,000; Hb, 60\% ; colour index, 1.1 ; red cells showed marked anisocytosis with macrocytes, microcytes, poikilocytes, an occasional diffuse polychromasic cell, and an occasional cell showing punctate basophilia ; white cells, 3,400 (polymorphs $60 \%$, lymphocytes $38 \%$, monocytes $2 \%$ ).

Intensive liver therapy was started on May 9, when the blood count showed : red cells, 2,550,000; $\mathrm{Hb}, 60 \%$; colour index. 1.2 ; white cells, 5,400 ; reticulocytes, $1.5 \%$. On May 15 the blood count was : red cells, 3,670,000; $\mathrm{Hb}, 70 \%$; colour index, 0.97 ; white cells, 9,800 ; reticulocytes, $9.5 \%$. On May 22 it was : red cells, 4,600,000; $\mathrm{Hb}, 90 \%$; colour index, 0.98 ; white cells, 7,700; ret:culocytes, $2.5 \%$. A histamine test meal revealed complete achlorhydria; the blood Wassermann reaction was negative.

$X$-ray reports were as follows:-May 9: "There is some increased opacity at the right lung base"; May 15 (opaque meal); "Stomach is rather small, shows normal tone; peristalsis somewhat diminished; mucosal pattern normal. Pyloric antrum appears to be narrowed, but peristaltic waves pass through this portion and it is distensible. No evidence of gastric ulcer. Duodenal cap is ląrge, fills out readily, has a normal contour, and is neither tender nor spastic. No evidence of duodenal ulcer."

Gastroscopy revealed small reddish nodular protuberances at the angulus; antral peristalsis and pyloric closure active. Impression, neoplasm.

At laparotomy on May 27 the surgeon was induced to perform a not very extensive resection of the lower third of the stomach. On opening this a nodular area was seen on the mucosa of the stomach on the lesser curve near to the pylorus, not adherent to the outer coats.

Pathological report by $D r$. L. R. Janes.- " The suspicious plaque in the stomach wall shows an adenomatoid appearance of the mucosa with increase in the number of the glands and hyperchromatism of the cells. The cellular arrangement in the gland acini is everywhere regular save at one point where, in a single acinus, there is a de-differentiation of epithelium, the cells of which cannot be identified as gastric epithelium. ? Earliest possible malignant change. The muscularis mucosae is prominent and intact."

The patient was discharged on June 27 , and is progressing well.

Comment.-The radiological appearances resembled those in Case 9. Gastroscopically, the anguius was clearly abnormal. Histologically, the thin mucosa, with definite superficial intestinal heterotopia, thickens, Prof. Stewart comments, to about five times its depth, with hyperchromatic vegetative epithelium, no doubt proliferating actively. This appearance is probably precancerous, and in a single acinus Dr. Janes now recognizes genuine early carcinomatous de-differentiation. The general picture much resembles appearances described by Waldeyer (1867) at the site of origin of gastric cancers, when, by serial sections, he first clearly showed their origin in the mucosa and not in connective tissues; and is similar to the areas of malignant degeneration in intestinal polyps (Saint, 1927) and to the non-invasive carcinoma in situ of the pars pylorica described by Mallory (1940). I feel strongly that it would have been most dangerous to leave the stomach unoperated and that the history of Case 9 would have been repeated. The case must be regarded as one of cancer, and if there is retrospective criticism it is, as Prof. Hardy has said, that the excision was not wide enough.

\section{Case 11}

A violinist and violin maker aged 70 was diagnosed as suffering from pernicious anaemia at Middlesex Hospital m 1934 and has been treated continuously since. On May 30, 1947, he was in good health. An opaque meal showed a pyloric antrum somewhat narrowed, but peristaltic wares passed through this region, which is against the presence of malignant neoplasm. Otherwise, nothing abnormal was discovered in stomach or duodenum, though the stomach is small and empties rapidly.

Gastroscopy on June 25 revealed some difficulty in passing the cardia, but nothing abnormal seen in this area. The angulus appeared irregularly nodular and the pylorus indurated and closing irregularly. On Aug. 24 he was admitted for laparotomy, symptom-free. A blood count showed : red cells, $4,970,000 ; \mathrm{Hb}, 94 \%$; colour index, 0.95 ; Wassermann reaction negative. On the night before operation he developed rightsided pneumonia. A radiograph on Oct. 7 showed lung fields clear except for thickened interlobar septum. Laparotomy on Oct. 8 revealed a large hard malignant ulcer of the antrum invading the peritoneum, with secondary growths in liver, glands of portal fissure, and pelvic peritoneum.

Comment.-This case was an advanced but asymptomatic carcinoma, which might have been detected if $x$-ray examination had been carried out earlier. The diagnosis of pernicious anaemia made at the Middlesex Hospital is accepted, and appears to be confirmed by the length of history. Radiologically, antral change was more advanced 
than in the two earlier cases, but of the same type ; and surgically only the lower third of the stomach was involved. Gastroscopy left little doubt of the diagnosis, but, as in some of these cases, infiltration at the angulus probably imitated the pylorus closely.

\section{Other Cases}

Case 8 was that of a woman of 60 with a four-year history of anaemia needing continued intensive liver therapy. She was found at operation to have a small stomach, only 2 to 3 in. ( 5 to $7.5 \mathrm{~cm}$.) in diameter, with a dumbbell-shaped tumour in the fundus ; this was removed with difficulty, and consisted of a benign leiomyoma. Case 15 is that of a man of 77 with a one-year history who has a sedimentation rate, repeated at several months' interval, of $30 \mathrm{~mm}$. : normal for the method, 0-10 $\mathrm{mm}$. only. $X$-ray examination showed a normal stomach, but gastroscopy revealed a reddish nodule on the greater curve of an otherwise (gastroscopically) normal pyloric antrum. This patient is still under observation, though unsuitable for operation without stronger reason.

These cases illustrate the recognized liability of patients with pernicious anaemia to gastric abnormality, and the desirability of watching them from this point of view.

\section{Discussion}

The limitations of this investigation are recognized. Swayed by the weight of others'. experience (Wilkinson, 1945) and by the apparently negative result of the first case, observations have been more casual than now seems desirable. The results justify further observation. Investigation in these cases is not difficult: the patients are generally placid and co-operative, their stomachs are easy to examine radiologically (Rigler, Kaplan, and Fink, 1945: and gastroscopically, and they tolerate operation well even in the eighth decade.

Of 15 patients examined for gastric lesions while free from dyspepsia, carcinoma has been found in three. In these cases the carcinomatous area was in the lower third, where radiology demonstrated narrowing even in the two cases which were at a very early stage. There seems to be no pathological reason for this general contraction of the pyloric area, though it may be the first indication of carcinomatous change. On the other hand, it may be a permanent characteristic of these stomachs. It was not productive of delay, and is not menticned by Jacobson and Palmer (1943) in a radiological study of gastric emptying in pernicious anaemia. The lower stomach is not usually abnormal in pernicio':s anaemia (Magnus and Ungley, 1938), and gastroscopy confirms this. An abnormal antral mucosa, especially when associated with a narrow antral canal, may predispose to malignancy. It is well recognized that the picpyloric area is particularly liable to develop cancer. Cases of pernicious anaemia showing an abnormal mucosa there should be viewed with as much suspicion as hyperchlorhydric cases with prepyloric ulcers. There is reason to believe, also, that simple neoplasms of the stomach are unduly frequent in pernicious anaemia. Carcinoma originating in these may appear in any gastric area, and is characteristically a bulky polypoid tumour. No such case has been found in the small number now reported, though I have records of other casual ones.

Conceivably, therefore, in pernicious anaemia carcinoma may arise in two ways. It is suggested as a basis for further full observation that the commoner prepyloric carcinoma does not arise in localized polyposis but is associated with rather diffuse mucosal changes detectable by gastroscopy at an early stage, and with narrowing of the prepyloric area demonstrable radiologically.

The patients developing carcinoma were all over the age of 65 , and had been treated for ten years or more. With increasing age abnormal stomachs would be expected to become more liable to malignant change ; and liver treatment, by keeping patients alive, may predispose to this form of cancer-if liver extract is not a carcinogen (Kaplan and Rigler, 1947).

The cases observed indicate once again how late in the course of gastric cancer symptoms appear. If, however, these cases are operated on early, then, as Mallory (1940) remarks of early gastrectomy for other prepyloric lesions, histological appearances are not infrequently doubtful. To cure more cancers we must alter our pathological, radiological, and gastroscopic criteria so as to present our histologists with precisely this problem. Kaplan and Rigler (1947) urge that watching cases of pernicious anaemia is the main method of achieving this object obvious at the moment, few as such cases are.

\section{Summary}

Examination of 15 symptom-free pernicious-anaemia patients revealed cancer in three. Periodical $x$-ray and gastroscopic studies are strongly indicated in all cases of Addison's anaemia in remission or relapse.

I am grateful to my hospital colleagues, especially to Dr. L. R Janes, for much help and restraining criticism. I am indebted to Prof. T. L. Hardy for encouragement and advice, and to Prof. M. J Stewart for comments on the histology of Case 2.

REFERENCES

Jacobson, L. O., and Palmer, W. L. (1943). Gastroenterology 1,1133 .

Kaplan, H. S., and Rigler, L. G. (1945). Amer. J. med. Sci. 209, 339

- (1947). J. Lab. clin. Med., 32, 644

Manus, H. A., and Ungley, C. C. (1938). Lancet, 1, 420.

Mallory T. B. (1940). Arch. Path 30, 348.

Rigler, L. G., Kaplan, H. S., and Fink, D. L. (1945). J. Amer. med Ass., 128, 426.

Saint, J., H. (1927). Brit. J. Surg., 15, 99.

Waldeyer (1867). Virchows Arch.. 41, 470.

Whitby, L. E. H., and Britton, C. J. C. (1946). Disorders of the Blood, 5th ed $p$ 236. London.

Wilkinson, J. F. (1945). British Medical Journal, 2, 664.

\section{THE COMPLICATIONS OF MUMPS}

BY

\author{
DESMOND LAURENCE, M.B., M.R.C.P. \\ Late Major, N.Z.M.C. \\ ANin
}

DONALD McGAVIN, M.Ch., F.R.C.S. Late Major, N.Z.M.C.

Officers Commanding Medical and Surgical Divisions, 6 New Zealand General Hospital, Japan

In 1946 a few cases of mumps occurred in a military camp in New Zealand just before the departure of a contingent of about 2,000 soldiers for Japan. A number of cases occurred on the ship during the journey, and after the arrival of the force in Japan the disease spread rapidly, giving rise to a sharp epidemic of 235 cases in seven months. It has since been possible to follow up 208 of these cases and to examine and to interrogate them. This paper embodies the result of the investigation, which was of particular interest so far as the complications of the disease and their permanent after-effects are concerned. Of the 208 patients 189 were white men, 14 were Maoris, and 5 were white women. There was no difference in the course of the disease in the Maoris except that they did not report sick until much later in the illness. Except where specially mentioned the figures refer to the 203 men, whose average age was 22 years, the women being considered separately.

We believe the value of this investigation lies largely in the fact that such a complete follow-up was possible so long 